\title{
ИСПОЛЬЗОВАНИЕ НАТУРАЛЬНЫХ ЗАКВАСОК ПРИ ПРОИЗВОДСТВЕ ХЛЕБОБУЛОЧНЫХ ИЗДЕЛИЙ ФУНКЦИОНАЛЬНОГО НАЗНАЧЕНИЯ, ОБОГАЩЕННЫХ КАЛЬЦИЕМ, КЛЕТЧАТКОЙ, БЕЛКОМ И З-КАРОТИНОМ
}

\section{I.V. Matseychik, S.M. Korpacheva, E.A. Suvorova}

\section{THE USE OF NATURAL STARSTERS IN THE PRODUCTION OF FUNCTIONAL PURPOSE BAKERY PRODUCTS ENRICHED WITH CALCIUM, CELLULOSE, PROTEIN AND $\beta$-CAROTIN}

Мацейчик Ирина Владимировна - канд. техн. наук, доц. каф. технологии и организации пищевых производств Новосибирского государственного технического университета, г. Новосибирск. E-mail: macejchik@corp.nstu.ru

Корпачева Светлана Михайловна - ст. преп. каф. технологии и организации пищевых производств Новосибирского государственного технического университета, г. Новосибирск.

E-mail: korpacheva@corp.nstu.ru

Суворова Екатерина Александровна - магистрант каф. технологии и организации пищевых производств Новосибирского государственного технического университета, г. Новосибирск.

E-mail: suvorova_6229@mail.ru

Цель исследования - разработка технологий хлебобулочных изделий, приготовленных на основе жидкой и сухой закваски спонтанного брожения с использованием сухой подсырной деминерализованной сыворотки «ВиммБилль-Данн», тонкодисперсного порошка яичной скорлупы механохимической обработки и растительного порошка инфракрасной сушки моркови. Исследована возможность замены в рецептурах хлебобулочных изделий функционального назначения прессованных хлебопекарных дрожжей на натуральные закваски спонтанного брожения, с использованием активных хлебопекарных ингредиентов «Back Natur» и "O-tenic». Показано влияние технологических параметров и режима приготовления тестовых полуфабрикатов на качество жидкой закваски, разведенной с помощью активного хлебопекарного ингредиента «Back Natur». Получены экспериментальные данные по микробиологическому составу сухой и жидкой закваски. На кафредре технологии и организации
Matseychik Irina Vladimirovna - Cand. Techn. Sci., Assoc. Prof., Chair of Technology and Organization of Food production, Novosibirsk State Technical University, Novosibirsk.

E-mail: macejchik@corp.nstu.ru

Korpacheva Svetlana Mikhaylovna - Senior Lecturer, Chair of Technology and Organization of Food production, Novosibirsk State Technical University, Novosibirsk.

E-mail: korpacheva@corp.nstu.ru

Suvorova Ekaterina Alexandrovna - Magistrate Student, Chair of Technology and Organization of Food production, Novosibirsk State Technical University, Novosibirsk.

E-mail: suvorova_6229@mail.ru

пищевых производств Новосибирского государственного технического университета были разработаны технологии новых хлебобулочных изделий на основе заквасок спонтанного брожения с использованием сухой подсырной деминерализованной сыворотки «Вимм-Билль-Данн», тонкодисперсного порошка яичной скорлупы механохимической обработки, растительного порошка из моркови инфракрасной сушки. Совместно с лабораторией биохимии Сибирского федерального научного иентра агробиотехнологий был определен химический состав и оптимальная дозировка вносимых добавок. Яичную скорлупу обрабатывали до получения тонкодисперсного порошка в лаборатории Института химии твердого тела и механохимии СО РАН. Порошок моркови после инфракрасной сушки при температуре $60-70^{\circ} \mathrm{C}$ в течение 180-240 мин измельчали в стружку со среднеэквивалентным размером частии 125-140 мкм и после механической и механохимической активации 
исследовали на количество водорастворимых веществ. Готовые хлебобулочные изделия исследовали по органолептическим, фризикохимическим и микробиологическим показателям качества. Потребление разработанных хлебобулочных изделий на основе заквасок удовлетворяет от 10 до $15 \%$ от суточной потребности организма в $\beta$-каротине, клетчатке, кальции и белке, что свидетельствует об их фуннкциональности. Разработанные хлебобулочные изделия рекомендованы в качестве функциональных продуктов для диетического и геронтологического питания.

Ключевые слова: закваска спонтанного брожения, активный хлебопекарный ингредиент, фоункциональные продукты питания, хлебобулочные изделия, подсырная деминерализованная сыворотка, порошок яичной скорлупы, инфрракрасная сушка, растительнье порошки.

The research objective was the development of the technologies of the bakery products prepared on the basis of liquid and dry ferment of spontaneous fermentation with use of dry cheese demineralized whey "Wimm-Bill-Dann", fine powder of an egg shell of mechanochemical processing and vegetable powder of infrared carrots drying. The possibility of the replacement in the recipes of bakery products of functional purpose of baker's compressed yeast by natural ferments of spontaneous fermentation, with using active baking ingredients "Back Natur" and "O-tenic" was investigated. The influence of technological parameters and the mode of preparation of test semi-finished products on the quality of liquid starter culture, diluted using the active baking ingredient "Back Natur" were shown. Experimental data on microbiological composition of dry and liquid ferment were obtained. At the Department of Technology and Organization of Food Production of Novosibirsk State Technical University the technologies of new bakery products on the basis of the ferments of spontaneous fermentation with use of dry cheese demineralized whey "WimmBill-Dann", fine powder of an egg shell of mechanochemical processing, vegetable powder from carrots of infrared drying were developed. Together with the Laboratory of Biochemistry of the Siberian Federal Scientific Center of Agrobiotechnologies chemical composition and optimum dosage of brought additives was defined. The egg shell was processed before receiving fine powder in the Laboratory of the Institute of Solid State Chemistry and Mechanical Chemistry SB RAS. Carrots powder after infrared drying at the temperature of $60-70^{\circ} \mathrm{C}$ within 180-240 minutes was crushed in chips with middle equivalent size of particles of 125-140 microns, and after mechanical and mechanical and chemical activation the amount of water-soluble substances was investigated. Finished bakery products were investigated on organoleptic, physical and chemical and microbiological indicators of quality. The consumption of developed bakery products on the basis of ferments satisfied from 10 to $15 \%$ of daily requirement of an organism in $\beta$-carotin, cellulose, calcium and protein that testifies to their functionality. The developed bakery products are recommended as functional products for dietary and gerontological food.

Keywords: spontaneous fermentation yeast, active baking ingredient, functional food products, bakery products, cheese demineralized whey, powder eggshells, infrared drying, vegetable powders.

Введение. На сегодняшний день приоритетным направлением в развитии хлебопекарной промышленности является разработка технологий и рецептур хлебобулочных изделий с использованием натуральных заквасок спонтанного брожения. Высокая популярность хлебопекарных заквасок различного состава связано с потребностью сокращения количества прессованных хлебопекарных дрожжей в рецептурах хлебобулочных изделий.

Добавление в рецептуры хлебобулочных изделий хлебопекарных заквасок позволяет наиболее эффрективно бороться с плесневением и картофельной болезнью, а также позволяет повысить качество готовых изделий и обогатить продукцию различными нутриентами.

Целью исследования: разработка технологий хлебобулочных изделий, приготовленных на основе жидкой и сухой закваски спонтанного брожения с использованием сухой подсырной деминерализованной сыворотки «Вимм-Билль-Данн», тонкодисперсного порошка яичной скорлупы механохимической обработки и растительного порошка инфрракрасной сушки моркови. 


\section{Задачи исследовния:}

- провести сравнительную характеристику сухой и жидкой закваски с прессованными дрожжами, определить технологические параметры и микробиологические показатели;

- обосновать выбор функциональных добавок и определить их оптимальную дозировку;

- исследовать влияние внесенных добавок на органолептические, фризико-химические и микробиологические показатели качества изделий;

- обосновать функциональные свойства новых хлебобулочных изделий.

Объекты и методы исследования. В данном исследовании для приготовления жидкой закваски использовали активный хлебопекарный ингредиент «Back Natur», состоящий из спельтовой муки, цветочного меда и морской соли, и активный хлебопекарный ингредиент «O-tenic», который представляет собой смесь сухой пшеничной и ржаной закваски спонтанного брожения.

На основе активных хлебопекарных ингредиентов были приготовлены следующие образцы заквасок:
- образец № 1 (контрольный образец) - хлебопекарные прессованные дрожжи «Люкс»;

- образец № 2 - сухая закваска «O-tenic»;

- образец № 3 - жидкая закваска, приготовленная из муки первого сорта, воды и активного хлебопекарного ингредиента «BackNatur»;

- образец № 4 - жидкая закваска, приготовленная из муки первого сорта и цельнозерновой муки в соотношении 1:1, воды и активного хлебопекарного ингредиента «Back Natur».

Для определения оптимальных условий разведения жидкой закваски ее готовили из цельнозерновой муки и муки первого сорта, воды и активного хлебопекарного ингредиента «Back Natur», вносимого в количестве $20 \%$ к массе муки. Брожение проводили в термостате при температуре $26{ }^{\circ} \mathrm{C}$ в течение 12,24 и 36 ч. Свойства заквасок оценивали по общей кислотности титриметрическим методом [7]. Влияние температуры и продолжительности брожения на общую кислотность заквасок представлено в таблице 1.

Таблица 1

Влияние температуры и продолжительности брожения на показатели качества заквасок

\begin{tabular}{|c|c|c|c|}
\hline \multirow[b]{2}{*}{ Образец } & \multicolumn{2}{|c|}{ Технологический параметр } & Кислотность, ${ }^{\circ} \mathrm{H}$ \\
\hline & $\begin{array}{l}\text { Температура } \\
\text { брожения, }{ }^{\circ} \mathrm{C}\end{array}$ & $\begin{array}{c}\text { Время брожения, } \\
4\end{array}$ & \\
\hline Образец № 1 (контрольный) & 26 & 1 & 4 \\
\hline \multirow{3}{*}{ Образец № 2} & \multirow{3}{*}{26} & 0,5 & 16,5 \\
\hline & & 1 & 18 \\
\hline & & 1,5 & 17,8 \\
\hline \multirow{3}{*}{ Образец № 3} & \multirow{3}{*}{26} & 12 & 10 \\
\hline & & 24 & 11,7 \\
\hline & & 36 & 11,9 \\
\hline \multirow{3}{*}{ Образец № 4} & \multirow{3}{*}{26} & 12 & 10 \\
\hline & & 24 & 11,5 \\
\hline & & 36 & 12 \\
\hline
\end{tabular}

Анализ результатов по влиянию температуры и продолжительности брожения на показатели качества заквасок, приготовленных на активных хлебопекарных ингредиентах «Back Natur» и «O-tenic», выявил, что для сухой закваски «O-tenic» оптимальным временем брожения является 1 ч, при этом кислотность образца № 2 составляет $18{ }^{\circ} \mathrm{H}$. Для жидкой закваски оптимальным временем брожения является 36 ч, при этом кислотность образца № 3 с мукой первого сорта составляет $11,9^{\circ} \mathrm{H}$, а образца № 4 с мукой первого сорта и цельнозерновой мукой в соотношении $1: 1$ составляет $12^{\circ} \mathrm{H}$. 
При этом сухая закваска «O-tenic» проходит процесс брожения уже в тестовых заготовках, а жидкая закваска «Back Natur» спустя 36 ч брожения еще выстаивается 2 ч в тестовых заготовках, что значительно увеличивает процесс приготовления хлебобулочных изделий.

В заквасочном брожении и брожении на прессованных дрожжах результаты жизнедеятельности дрожжей и бактерий находятся между собой в подвижном равновесии, только с той разницей, что в тесте на прессованных дрожжах преобладает дрожжевое брожение, в заквасочном - молочнокислое брожение. В сравнении с прессованными дрожжами закваски за счет жизнедеятельности бактерий вызывают более энергичное накопление кислот в тесте и заметно сдвигают его рН в кислую зону. Поэтому истинная кислотность теста на заквасках превосходит кислотность теста на прессованных дрожжах, что мы наблюдаем по результатам эксперимента [8].

Приготовленные закваски спонтанного брожения были исследованы по микробиологическим показателям качества. Подсчет количества клеток микроорганизмов проводили методом определения количества аэробных и фракультативно анаэробных микроорганизмов в 1 г продукта (КМАФАМ). Результаты исследования представлены в таблице 2.

Таблица 2

\section{Определение количества аэробных и факультативно анаэробных микроорганизмов в 1 г продукта (КМАФАМ)}

\begin{tabular}{|l|c|}
\hline \multicolumn{1}{|c|}{ Образец } & Содержание, КОЕ/г \\
\hline Образец № 1 (контрольный) & $1,1 \cdot 10^{6}$ \\
\hline Образец № 2 & $4 \cdot 10^{4}$ \\
\hline Образец № 3 & $1 \cdot 10^{4}$ \\
\hline Образец № 4 & $2,5 \cdot 10^{4}$ \\
\hline
\end{tabular}

Исходя из полученных данных, можно сделать вывод, что все приготовленные образцы по показателям КМАФАМ, КОЕ/г, соответствуют показателям безопасности согласно СанПиН 2.3.2.1078-01 [3].

Сухая деминерализованная подсырная сыворотка - продукт переработки молока, полученный при производстве сыра в результате высушивания подсырной сыворотки, из которого удалена часть минеральных солей. Деминерализованный сухой продукт обладает улучшенными органолептическими характеристиками, большей растворимостью и меньшей кислотностью.

Сыворотка состоит из $97 \%$ сухого остатка молока, в том числе белков (альбуминов и глобулинов), которые обладают высокой биологической ценностью и имеют наивысшие среди цельных белков скорость расщепления и степень усвояемости. Содержащиеся белки служат дополнительным источником аргинина, гистидина, метионина, треонина, триптофана и лейцина. Это позволяет отнести их к полноценным белкам, используемым организмом для регенерации белков печени, образования гемоглобина и плазмы крови.

В состав подсырной сыворотки входит лактоза (90\%), тонко диспергированный молочный жир, комплекс жизненно важных макро- и микроэлементов (магний, калий, кальций, фосфор), никотиновая кислота и биотин, а также холин и витамины групп A, B, C, E, органические кислоты [9].

Таким образом, подсырная сыворотка является ценным сырьем при разработке технологий и рецептур хлебобулочных изделий функционального назначения.

Одним из основных отклонений от принципов сбалансированного питания для детей, в том числе современных школьников, а также пожилых людей, является недостаточное потребление кальция.

Человеческий организм не способен самостоятельно синтезировать кальций и зависит от обеспеченности элементом извне. Наибольшую пользу могут оказать только те сис- 
темы, в которых кальций находится в биологически активном состоянии. Одной из таких систем является яичная скорлупа. Скорлупа куриных яиц на 97 \% состоит из неорганического вещества - солей карбоната кальция, который усваивается почти полностью за счет того, что уже проходил синтез в организме птиц из кальция в составе органических соединений в неорганические.

В яичной скорлупе содержится не только легкоусвояемый кальций, но и другие важные для человека минеральные элементы, например магний, фосфрор, кремний, натрий, калий, железо, сера и другие компоненты. В составе протеина присутствуют незаменимые аминокислоты, например метионин, цистин, лизин, изолейцин.

Учитывая полезные свойства яичной скорлупы, ее вводили в рецептуры хлебобулочных изделий после измельчения.

Яичную скорлупу после санитарной обработки и прокаливания измельчали на дезинтеграторе Desi-11 в лаборатории Института химии твердого тела и механохимии СО РАН.

Средневзвешенный размер частиц 25 мкм - определен методом дифракции лазерного луча на приборе Microsizer 201 (г. СанктПетербург) (рис.).

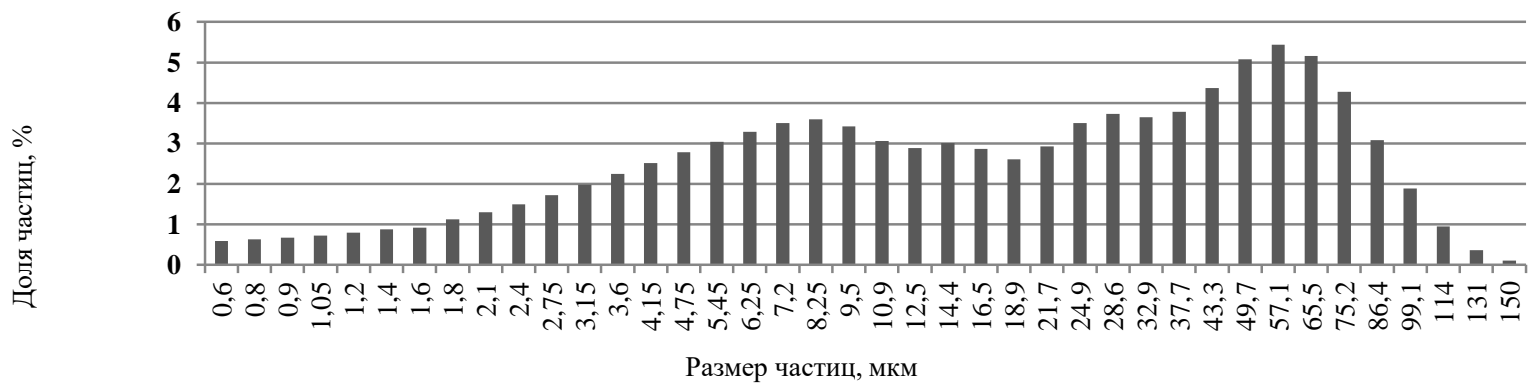

Средневзвешенный размер частии

Площадь поверхности была определена методом БЭТ (С. Брунауэра, П. Эммета и Э. Тейлора) на приборе Сорбтометр (г. Новосибирск) - 5,2 м²/г.
Был определен химический состав тонкодисперсного порошка яичной скорлупы, которые представлены в таблице 3.

Химический состав порошка яичной скорлупы

\begin{tabular}{|l|c|c|}
\hline \multicolumn{1}{|c|}{ Показатель, \% } & $\begin{array}{c}\text { Нормативная документация } \\
\text { на методы испытаний }\end{array}$ & $\begin{array}{c}\text { Фактическое } \\
\text { значение }\end{array}$ \\
\hline Сухие вещества & ГОСТ 31640-2012 & $98,75 \pm 0,5$ \\
\hline Массовая доля белка & ГОСТ 32044.1-2012 & $20,59 \pm 0,4$ \\
\hline Массовая доля золы & ГОСТ 26226-95 & $78,16 \pm 1,2$ \\
\hline Массовая доля кальция & ГОСТ26570-95 & $54,43 \pm 0,5$ \\
\hline Массовая доля фоссрора & ГОСТ 26657-85 & $0,31 \pm 0,2$ \\
\hline
\end{tabular}

По результатам исследований было выявлено, что содержание кальция в измельченной скорлупе составляет $54,43 \%$, белка $20,59 \%$.
В рецептуры хлебобулочных изделий вводился порошок инфракрасной сушки моркови для улучшения усвоение кальция, содержащегося в порошке яичной скорлупы, повышения 
витаминно-минерального состава, в том числе обогащения $\beta$-каротином и антиоксидантами.

Полезные свойства моркови объясняются химическим составом, основная ценность которого - $\beta$-каротин (12\%), а также пектины и минеральные вещества (K, P, Fe, Cu, F). Mopковь также богата витаминами $\mathrm{B}_{1}, \mathrm{~B}_{2}, \mathrm{~B}_{6}, \mathrm{C}, \mathrm{K}$.

Технология получения растительного порошка заключается в получении стружки моркови с сечением $20 \times 4$ мм, ее сушке при температуре $60-70{ }^{\circ} \mathrm{C}$ в течение $180-240$ мин до влажности 8ะ0,5 \% и измельчении высушенной стружки в порошок со среднеэквивалентным размером частиц 125-140 мкм [5].

После механической и механохимической активации образца с различными добавками в нем определяли максимальное количество водорастворимых веществ (ВРВ, мас.\%). Механическую активацию образца осуществляли в барабанах планетарной центробежной мельницы - активатора типа АПФ-ЗМ. Результаты эксперимента представлены в таблице 4.

Таблица 4

\section{Определение количества водорастворимых веществ в порошке инфракрасной сушки моркови}

\begin{tabular}{|c|c|c|c|}
\hline Показатель & \multicolumn{3}{|c|}{ Порошок моркови } \\
\hline Активация, добавки & $\begin{array}{l}\text { Номер } \\
\text { опыта }\end{array}$ & $\begin{array}{c}\text { BPB, мас.\%, } \\
\text { (раствор, осадок) }\end{array}$ & $\begin{array}{l}\mathrm{pH} \text { и цвет } \\
\text { раствора }\end{array}$ \\
\hline $\begin{array}{l}\text { Измельчение, } \\
\text { фракция менее } 2 \text { мм }\end{array}$ & 1682 & $\begin{array}{l}37,4 \\
37,7\end{array}$ & $\begin{array}{c}5,5 \\
\text { (светло-желтый) }\end{array}$ \\
\hline Механохимическая активация & 1683 & $\begin{array}{l}37,9 \\
38,3\end{array}$ & $\begin{array}{c}5,4 \\
\text { (светло-желтый) }\end{array}$ \\
\hline$+5 \% \mathrm{NaHCO}_{3}$ & 1684 & $\begin{array}{c}62 \\
61,3\end{array}$ & $\begin{array}{c}7,5 \\
\text { (светло-коричневый) }\end{array}$ \\
\hline$+5 \% \mathrm{Na}_{2} \mathrm{CO}_{3}$ & 1685 & $\begin{array}{l}56,1 \\
54,3\end{array}$ & $\begin{array}{c}7,7 \\
\text { (светло-коричневый) }\end{array}$ \\
\hline$+5 \% \mathrm{NaOH}$ & 1686 & $\begin{array}{l}46,9 \\
45,7\end{array}$ & $\begin{array}{c}8,6 \\
\text { (светло-коричневый) }\end{array}$ \\
\hline$+5 \% \mathrm{H}_{3} \mathrm{PO}_{4}$ & 1687 & $\begin{array}{l}55,5 \\
55,6\end{array}$ & $\begin{array}{c}4,3 \\
\text { (светло-желтый) }\end{array}$ \\
\hline$+10 \%$ caxapa & 1688 & $\begin{array}{c}53,1 \\
52 \\
\end{array}$ & $\begin{array}{c}5,3 \\
\text { (желтый) }\end{array}$ \\
\hline +5 \% аскорбиновой кислоты & 1689 & $\begin{array}{l}45,7 \\
42,7\end{array}$ & $\begin{array}{c}4,6 \\
\text { (светло-желтый) }\end{array}$ \\
\hline Влажность, $60{ }^{\circ} \mathrm{C}$, мас. $\%$ & & 3,7 & \\
\hline Зольность, $900{ }^{\circ} \mathrm{C}$, мас. $\%$ & & 5,4 & \\
\hline
\end{tabular}

Установлено, что процент ВРВ в порошке повышается после его механохимической активации. Самый большой выход ВРВ был получен в порошке ИК-сушки моркови после добавления $5 \% \mathrm{NaHCO}_{3}$.

На кафедре был определен химический состав растительного порошка инфракрасной сушки, который представлен в таблице 5. Определение антиоксидантной активности (АОА) проводилось амперометрическим методом в соответствии с методикой выполнения измерения водорастворимых антиоксидантов № 31-07 от 4 мая 2007 г. 
Химический состав морковного порошка ИК-сушки

\begin{tabular}{|l|c|}
\hline \multicolumn{1}{|c|}{ Показатель } & Содержание веществ в 100 г \\
\hline Влажность, \% & $14,0 \pm 0,01$ \\
\hline Белки, \% & $8,1 \pm 0,02$ \\
\hline Жиры, \% & $1,5 \pm 0,1$ \\
\hline Сахара, \% & $63,9 \pm 0,14$ \\
\hline Клетчатка, \% & $7,2 \pm 0,11$ \\
\hline Крахмал, \% & $0,8 \pm 0,1$ \\
\hline Пектин, \% & $1,5 \pm 0,12$ \\
\hline Зольность, \% & $3 \pm 0,01$ \\
\hline Na, мг & $59,0 \pm 0,1$ \\
\hline К, мг & $967,0 \pm 0,2$ \\
\hline Са, мг & $105,0 \pm 0,14$ \\
\hline Мg, мг & $56,0 \pm 0,2$ \\
\hline Fе, мг & $3,0 \pm 0,1$ \\
\hline Витамины: $\beta$-каротин, мг & $0,67 \pm 0,07$ \\
\hline \multicolumn{1}{|c|}{ АОА, мкг } & $0,25 \pm 0,08$ \\
\hline
\end{tabular}

При определении химического состава морковного порошка ИК-сушки установлено, что морковный порошок инфракрасной сушки обладает высокими показателями пищевой ценности и антиоксидантной активностью ( $\beta$ каротин, кверцетин), что позволяет использовать его в качестве ингредиента при разработке продукции функцционального назначения.

На основе комплексных добавок были разработаны следующие образцы хлебобулочных изделий:

- образец № 1 (контрольный образец) хлебобулочное изделие «Морковная» на основе прессованных дрожжей с использованием подсырной деминерализованной сыворотки, овсяных хлопьев, тонкодисперсного порошка ИК-сушки моркови и порошка яичной скорлупы;

- образец № 2 - хлебобулочное изделие на основе сухой закваски "O-tenic» с использованием подсырной деминерализованной сыворотки, овсяных хлопьев, тонкодисперсного порошка ИК-сушки моркови и порошка яичной скорлупы;

- образец № 3 - хлебобулочное изделие на основе сухой закваски «O-tenic» с добавлением цельнозерновой муки в соотношении 1:1 к муке первого сорта, подсырной деминерализованной сыворотки, овсяных хлопьев, тонкодисперсного порошка ИК-сушки моркови и порошка яичной скорлупы;

- образец № 4 - хлебобулочное изделие на основе жидкой закваски «Back Natur» с использованием подсырной деминерализованной сыворотки, овсяных хлопьев, тонкодисперсного порошка ИК-сушки моркови и порошка яичной скорлупы;

- образец № 5 - хлебобулочное изделие на основе жидкой закваски «Back Natur» с добавлением цельнозерновой муки в соотношении 1:1 к муке первого сорта, подсырной деминерализованной сыворотки, овсяных хлопьев, тонкодисперсного порошка ИК-сушки моркови и порошка яичной скорлупы.

Результаты исследования. Образцы новых хлебобулочных изделий были исследованы по органолептическим, фризико-химическим и микробиологическим показателям, определенным согласно стандартным методикам.

Для объективного контроля качества образцов применялся метод органолептической оценки, который заключается в прямой рейтинговой оценке качества, в соответствии с ГОСТ 5667-65 [2]. Органолептическая оценка новых хлебобулочных изделий представлена в таблице 6. 
Органолептическая оценка исследуемых образцов, баллов

\begin{tabular}{|l|c|c|c|c|c|}
\hline $\begin{array}{c}\text { Показатель } \\
\text { качества }\end{array}$ & $\begin{array}{c}\text { Образец № 1 } \\
\text { (контрольный) }\end{array}$ & $\begin{array}{c}\text { Образец } \\
\text { № 2 }\end{array}$ & $\begin{array}{c}\text { Образец } \\
\text { № 3 }\end{array}$ & $\begin{array}{c}\text { Образец } \\
\text { № 4 }\end{array}$ & $\begin{array}{c}\text { Образец } \\
\text { № 5 }\end{array}$ \\
\hline Внешний вид & 5 & $4,9 \pm 0,5$ & $4,8 \pm 0,25$ & $3,75 \pm 0,3$ & 3 \\
\hline Цвет & 5 & $4,89 \pm 0,25$ & $4,8 \pm 0,25$ & 3 & 3 \\
\hline Вкус & $4,9 \pm 0,25$ & $4,9 \pm 0,25$ & $4,9 \pm 0,3$ & $2,5 \pm 0,3$ & $2,8 \pm 0,3$ \\
\hline Запах & $4,95 \pm 0,3$ & 5 & 5 & $4,8 \pm 0,3$ & $4,85 \pm 0,3$ \\
\hline Консистенция & 5 & 5 & $4,9 \pm 0,5$ & 3 & 3 \\
\hline
\end{tabular}

Проведенная органолептическая оценка новых хлебобулочных изделий показала, что образцы № 2 и 3, приготовленные на основе сухой закваски «O-tenic», характеризуются лучшими органолептическими показателями в сравнении с контрольным образцом, обладают приятным внешним видом, хорошим вкусом, цветом и запахом, пористой консистенцией. Образцы № 4 и 5 , приготовленные на основе жидкой закваски, по- лучили удовлетворительные показатели, так как была зафиксирована пониженная пористость, сыропеклый мякиш и пресный вкус. Это объясняется недостаточным временем брожения и расстойки хлебобулочных полуфабрикатов.

Физико-химические показатели качества были определены стандартными методами. Результаты исследования представлены в таблице 7.

\section{Физико-химические показатели качества образцов хлебобулочных изделий}

Таблица 7

\begin{tabular}{|l|c|c|c|c|c|}
\hline \multirow{2}{*}{ Показатель } & \multicolumn{5}{|c|}{ Образец } \\
\cline { 2 - 6 } & $\begin{array}{c}\text { Образец № 1 } \\
\text { (контрольный) }\end{array}$ & $\begin{array}{c}\text { Образец } \\
\text { № 2 }\end{array}$ & $\begin{array}{c}\text { Образец } \\
\text { № 3 }\end{array}$ & $\begin{array}{c}\text { Образец } \\
\text { № 4 }\end{array}$ & $\begin{array}{c}\text { Образец } \\
\text { № 5 }\end{array}$ \\
\hline Влажность, \% & $40,4 \pm 0,1$ & $35,63 \pm 0,13$ & $34,63 \pm 0,4$ & $38,5 \pm 0,4$ & $40,16 \pm 0,35$ \\
\hline Пористость, \% & $79 \pm 0,02$ & $60,3 \pm 0,049$ & $58,49 \pm 0,056$ & $19,39 \pm 0,046$ & $23,87 \pm 0,035$ \\
\hline $\begin{array}{l}\text { Удельный объем, } \\
\text { см³/г }\end{array}$ & $2,12 \pm 0,05$ & $1,92 \pm 0,03$ & $1,84 \pm 0,043$ & $0,94 \pm 0,045$ & $1,01 \pm 0,05$ \\
\hline $\begin{array}{l}\text { Содержание } \\
\text { клетчатки, г }\end{array}$ & $3,1 \pm 0,01$ & $3,1 \pm 0,01$ & $3,5 \pm 0,03$ & $3,1 \pm 0,01$ & $3,47 \pm 0,04$ \\
\hline $\begin{array}{l}\text { Содержание } \\
\text { кальция, мг }\end{array}$ & $480 \pm 0,03$ & $479 \pm 0,003$ & $480 \pm 0,04$ & $483 \pm 0,05$ & $481 \pm 0,024$ \\
\hline $\begin{array}{l}\text { Содержание } \\
\text { белка, г }\end{array}$ & $9,65 \pm 0,1$ & $9,62 \pm 0,5$ & $9,63 \pm 0,12$ & $9,61 \pm 0,12$ & $9,6 \pm 0,12$ \\
\hline $\begin{array}{l}\text { Содержание } \\
\beta \text {-каротина, мг }\end{array}$ & $0,75 \pm 0,07$ & $0,75 \pm 0,07-$ & $0,75 \pm 0,07$ & $0,75 \pm 0,07$ & $0,75 \pm 0,07$ \\
\hline Кислотность, ${ }^{\circ}$ H & $1,9 \pm 0,01$ & $2,5 \pm 0,02$ & $2,9 \pm 0,01$ & $2,3 \pm 0,02$ & $2,8 \pm 0,02$ \\
\hline АОА, мкг & $0,46 \cdot 10^{3} \pm 0,05$ & $0,46 \cdot 10^{3} \pm 0,05$ & $0,46 \cdot 10^{3} \pm 0,05$ & $0,46 \cdot 10^{3} \pm 0,05$ & $0,46 \cdot 10^{3} \pm 0,05$ \\
\hline
\end{tabular}

По результатам определения фризикохимических показателей качества всех образцов хлебобулочных изделий можно сделать следующие выводы:

- Пористость и удельный объем хлебобулочных изделий на сухой закваске составляет $60,3 \%$ и 1,92 см³/г (для образца № 2) и 58,49 \% и 1,84 см³/г (для образца № 3) соответственно.
Это чуть меньше, чем у контрольного образца, при этом пористость и удельный объем изделий снижаются при добавлении в рецептуры изделий цельнозерновой муки. У изделий на жидкой закваске показатели пористости и удельного объема имеют низкие результаты, что объясняется низкой газообразующей способностью самой закваски и тестовых полуфабрикатов [6]. 
- Установлено, что все образцы хлебобулочных изделий восполняют более $15 \%$ от нормы потребления $\beta$-каротина (0,75 мг) и кальция (150-180 мг), что свидетельствует об их функциональности.

- Установлено, что все образцы хлебобулочных изделий восполняют 10 \% от нормы потребления белка (9 г).

- $\quad$ За счет добавления в рецептуры овсяных хлопьев и цельнозерновой муки изделия являются обогащенными клетчаткой, восполняющими более $10 \%$ от суточной потребности [4].

Хлебобулочные изделия были исследованы на наличие микробиологической обсемененности. Установлено, что во всех исследуемых образцах не обнаружены бактерии группы кишечной палочки, S. Aureus и патогенных микроорганизмов рода Salmonella, что свидетельствует о соблюдении санитарного режима при производстве и требований ТР ТС 021/2011 [1].

Выводы. В ходе данного исследования были разработаны технологии хлебобулочных изделий на основе сухой и жидкой закваски спонтанного брожения с добавлением сухой подсырной деминерализованной сыворотки «ВиммБилль-Данн», овсяных хлопьев, морковного порошка инфракрасной сушки, тонкодисперсного порошка яичной скорлупы.

Экспериментально установлено, что хлебобулочные изделия на сухой закваске обладают лучшими результатами исследований по органолептическим и физико-химическим показателям качества, чем хлебобулочные изделия на жидкой закваске. Таким образом, проведя сравнительную характеристику сухой и жидкой заквасок, можно сделать вывод о том, что сухая закваска позволяет интенсифицировать процесс приготовления тестовых заготовок, упростить процесс приготовления теста, исключить процесс длительного выращивания закваски с соблюдением точных температурных показателей и показателей кислотности, так как является уже готовой закваской и добавляется в тесто в сухом виде. Сухая закваска в сравнении с прессованными дрожжами способствует накоплению в хлебобулочных изделиях вкусо-ароматических веществ, таких как фурфурол, ацетальдегид, формальдегид, метилглиоксаль и других, которые придают выраженный приятный вкус и аромат изделиям; способствует обогащению витаминами, антиоксидантами, а также множеством макро- и микроэлементов и защищает изделия от микробной порчи за счет антимикробных веществ, которые формируются естественным путем в процессе созревания закваски.

Введение в хлебобулочные изделия сухой подсырной деминерализованной сыворотки «Вимм-Билль-Данн» обогащает готовые хлебобулочные изделия белками и аминокислотами, а также позволяет интенсифицировать процессы приготовления тестовых полуфрабрикатов и готовых изделий.

Введение в рецептуры тонкодисперсного порошка яичной скорлупы и растительного порошка инфракрасной сушки моркови позволило обогатить хлебобулочные изделия полезными нутриентами, такими как кальций, витаминами С, Е, $\beta$-каротином, антиоксидантами и улучшить структурно-механические свойства теста и органолептические показатели готовых изделий.

По результатам органолептической оценки изделия на сухой закваске имеют хорошую пористость и состояние мякиша, улучшенные потребительские свойства в сравнении с изделиями на жидкой закваске.

По результатам физико-химических показателей качества разработанные изделия являются продуктами фрункционального назначения, восполняющими более $15 \%$ от суточной потребности по содержанию кальция, $\beta$-каротина и более $10 \%$ по содержанию белка и клетчатки.

Следовательно, разработанные хлебобулочные изделия на основе сухой закваски имеют высокий потенциал для внедрения в производство в качестве альтернативы хлебу, их можно рекомендовать для диетического и геронтологического питания.

\section{Литература}

1. ТP ТС 021/2011. О безопасности пищевой продукции (утв. решением Комиссии Таможенного союза от 9 декабря 2011 г. № 880). URL:http://docs.cntd.ru/document/902320557 (дата обращения: 10.09.2019).

2. ГОСТ 5667-65. Хлеб и хлебобулочные изделия. Правила приемки, методы отбора образцов, методы определения органолептических показателей и массы изделий. - 
Введ. 01.01.1966. - М.: Стандартинформ, 1991. - 5 C.

3. СанПиН 2.3.2.1078-01. Гигиенические требования к безопасности и пищевой ценности пищевых продуктов. - URL: http://docs.cntd.ru/document/901806306_(дата обращения: 10.09.2019).

4. MP 2.3.1.1915-04. Рекомендуемые уровни потребления пищевых и биологически активных веществ / Федер. центр Госсанэпиднадзора Минздрава России. - М., 2004. - 11 c.

5. Волончук С.К., Шорникова Л.П., Филлиманчук Г.П. Техника и технологии сушки растительного сырья с использованием инфакрасного излучения / РАСХН. Сиб. отд-ние. ГНУ СибНИТПТИП. - Новосибирск, 2006. $36 \mathrm{c}$.

6. Хамельман Дж. Хлеб. Технология и рецептуры / пер. с англ. О.П. Четвериковой. СПБ.: Профрессия, 2012. - 432 с.

7. Brandt M.J. Sourdough products for convenient use in baking // Food Microbiology. 2007. - № 24. - P. 161-164.

8. Buehler E. Bread Science: The Chemistry and Craft of Making Bread. - U.S.: Hillsboro, 2014.

9. Find by food. Demineralized Whey Powder. URL: https://www.tetrapak.com/nl/findbyfood/ whey-powder/de-mineralized-whey-powder (дата обращения: 10.09.2019).

\section{Literatura}

1. TR TS 021/2011. O bezopasnosti pishchevoj produkcii (utv. resheniem Komissii Tamozhennogo soyuza ot 9 dekabrya $2011 \mathrm{~g}$.
№ 880). - - URL:http://docs.cntd.ru/document/ 902320557 (data obrashcheniya: 10.09.2019).

2. GOST 5667-65. Hleb i hlebobulochnye izdeliya. Pravila priemki, metody otbora obrazcov, metody opredeleniya organolepticheskih pokazatelej i massy izdelij. Vved. 01.01.1966. - M.: Standartinform, 1991. $5 \mathrm{~s}$.

3. SanPiN 2.3.2.1078-01. Gigienicheskie trebovaniya $k$ bezopasnosti i pishchevoj cennosti pishchevyh produktov. - URL: http://docs.cntd.ru/document/901806306 (data obrashcheniya: 10.09.2019).

4. MR 2.3.1.1915-04. Rekomenduemye urovni potrebleniya pishchevyh i biologicheski aktivnyh veshchestv / Feder. centr Gossanepidnadzora Minzdrava Rossii. - M., 2004. - 11 s.

5. Volonchuk S.K., SHornikova L.P., Fillimanchuk G.P. Tekhnika i tekhnologii sushki rastitel'nogo syr'ya $s$ ispol'zovaniem infakrasnogo izlucheniya / RASKHN. Sib. otdnie. GNU SibNITPTIP. - Novosibirsk, 2006. $36 \mathrm{~s}$.

6. Hamel'man Dzh. Hleb. Tekhnologiya i receptury / per. s angl. O.P. CHetverikovoj. SPB.: Professiya, 2012. - $432 \mathrm{~s}$.

7. Brandt M.J. Sourdough products for convenient use in baking // Food Microbiology. 2007. - № 24. - P. 161-164.

8. Buehler E. Bread Science: The Chemistry and Craft of Making Bread. - U.S.: Hillsboro, 2014.

9. Find by food. Demineralized Whey Powder. URL: https://www.tetrapak.com/nl/findbyfood/ whey-powder/de-mineralized-whey-powder (data obrashcheniya: 10.09.2019). 